\title{
MALAYA'S NATIONAL PARK
}

\author{
By A. H. Fetherstonihugh
}

The original proposal for a National Park in Malaya was put forward by the late Theodore Hubback in 1927. Subsequent correspondence in which the Socicty for the Preservation of the Fauna of the Empire was interested, paved the way for concrete suggestions contained in the Report of the Wild Life Commission of Malaya, published in 1932.

It was not until 1938 that action was taken upon the Commission's recommendations but these were closely followed. 'Their Highnesses the Sultans of Pahang, Trengganu and Kelantan generously donated the land and State Parks were constituted which together form the King George V National Park. The terms of the dedication are given in Oryd, Vol. I, No. 2, p. 83, where there is also a map and a brief description of the principal natural features of the park. $A$ glossary of Malay words is given at the end of this article.

Between 1938 and 1941 the National Park progressed rapidly. Facilities provided aimed at reasonable comfort for staff and visitors without losing sight of the object of the Park. They infringed upon the demesne of the spirit of the Malayan. Jungle as little as was humanly possible. The headquarters station of the old Gunong Tahan Game Reserve was developed as Park Headquarters, a house for the Superintendent, simple administrative buildings staff, quarters and halting-bungalow being built. Staff quarters and halting-bungalows were also built at Kuala Tranggan, Kuala Kenyam and Kuala Kelapor, and staff quarters at Kuala Atok, Kuala Toh, Batu Lompat and Kuala Koh. At Kuala Ngeram the Assistant Superintendent's house and staff quarters were completed and a holiday camp was planned for crection at Padang Cherui. 'The broad plan was to develop the Tembeling Valley for visitors whose interests lay in observing and photographing wild life, and the Kuala NgeramPadang Cherui area for those placing observation second to a holiday in attractive surroundings.

The visitor entering the eastern side of the Park was provided for by a service of outboard motor boats. A walk of approximately twenty minutes from Tembeling railway station ended in a transit-store and halting-bungalow at Kuala Tembeling. From here fast roomy boats plied to Kuala 'Tahan, smaller motor-boats served the up-river posts and in turn gave place to poling boats on the tributaries. On the western side, mules wcre 
kept for transport between Merapoh railway station and Kuala Ngeram beyond which travel was on foot.

The Game Department's herd of four elephants was carmarked for the Park when catching operations in Perak were finished. It was hoped that this herd, augmented by part of the catch, would form the principal means of transport for parties penetrating beyond the regular routes outlined. Three were recovcred after the occupation, but of these one has died and another has been killed by bandits.

Although plans were still incomplete it was possible to handle small parties of visitors and the work of investigation and development was making stcady progress. In $1932 \mathrm{I}$ had accompanied T. R. Hubback on an expedition into the Gunong Padang area and this reconnaissance was being followed up by research into the incidence of the larger mammals, with special reference to rhinoceros and the suitability of this high plateau for the formation of an outpost station and a camping site for visitors.

On the outbreak of war in Malaya in 1941, the Park had to be abandoned. Some of the Malay staff remained quietly at their posts and the Chinese carctaker at Kuala Tahan continued to look after the halting-bungalow and the Superintendent's house. A Japanese reconnaissance party put a stop to all this; the caretaker was severely "questioned" on suspicion of having assisted certain European officers to cscape and the rangers scattered to their homes. What was not looted or destroyed was left to the mercies of the jungle which rapidly obliterated the work of years; all boats, engines, stores, instruments, and equipment were lost and irreplacable records disappeared. At Kuala Ngeram the newly-completed Assistant Superintendent's house and the staff quarters were burned as a potential hideout for guerillas.

The first officer to set foot in the Park again was the pre-war Superintendent, Mr. G. R. Leonard, M.B.E., who was dropped into Padang Cherui in 1945 as a major in Force 136.

When the country was liberated, all senior officers were still in the Forces or repatriated on leave subsequent to three and a half years as prisoners of war or civil internees. The Forest Department took over the affairs of the Game Department and most of the National Park staff reported to the State Forest Officer Pahang, for duty, in some cases wearing uniforms and badges which had been successfully hidden during the occupation. One senior ranger later produced a prismatic compass and stand, the only item out of many thousands of dollars worth of 
equipment which was recovered. The carctaker Chu Ah Jui, for many years my personal servant, and one ranger were dead, but only one of the survivors failed to return to duty within the period stipulated by Government. Boatmen and labourers were recruited from the Tembeling Kampongs, some old hands and others the sons and grandsons of men who had served the department in the past. Recruitment has always been from this rather restricted area, as these tough descendents of generations of river-men are in thoir natural element in the snags and rapids of the upper waters of the Tembeling and its tributaries.

Some money was made a vailable and the men started to clear secondary growth at the posts, ereet temporary buildings and persuade some of the families which had drifted into the Park from riverine kampongs near the boundarics, to move out again. It is a tribute to the goodwill on both sides and the tact of the Superintendent and his subordinates that not a single unpleasant incident occurred and not one trespasser was brought into court, although the process of eliminating illegal migrants took time and patience.

It was not until 1947 that sufficient oflicers became available to reorganize the department. Mr. C. S. Ogilvie went into the Park as Superintendent and proceeded to rcbuild his house. From the day he assumed duty Ogilvie has become the cmbodyment of Kipling's Hobden :--

"He is bailiff, wheelwright, wainwright, ficld surveyor, engineer."

Shortage of funds threw the Park staff largely upon their own resources and it was decided to build on the principle of putting in as much permanent material as possible in the first instance and completing with temporary construction. 'Thus a habitable building was erected at minimum cost in cash, time and labour, but in such a way that improvements could be made progressively as money and labour became available. A begimning had also to be made towards replacing the boats and it was decided to do this ourselves. Two old hands had returned to duty who were expert builders of boats of local pattern, and Mat Daud and his henchmen were set the task of finding suitable timber and making a start. Outside help was employed when we could afford it, particularly in the long and tedious job of making "lunas", but we had set up as boat-builders and have continued as such with no little success. Outboard motors have been gradually replaced and wo have almost as good a lleet as before the war. 


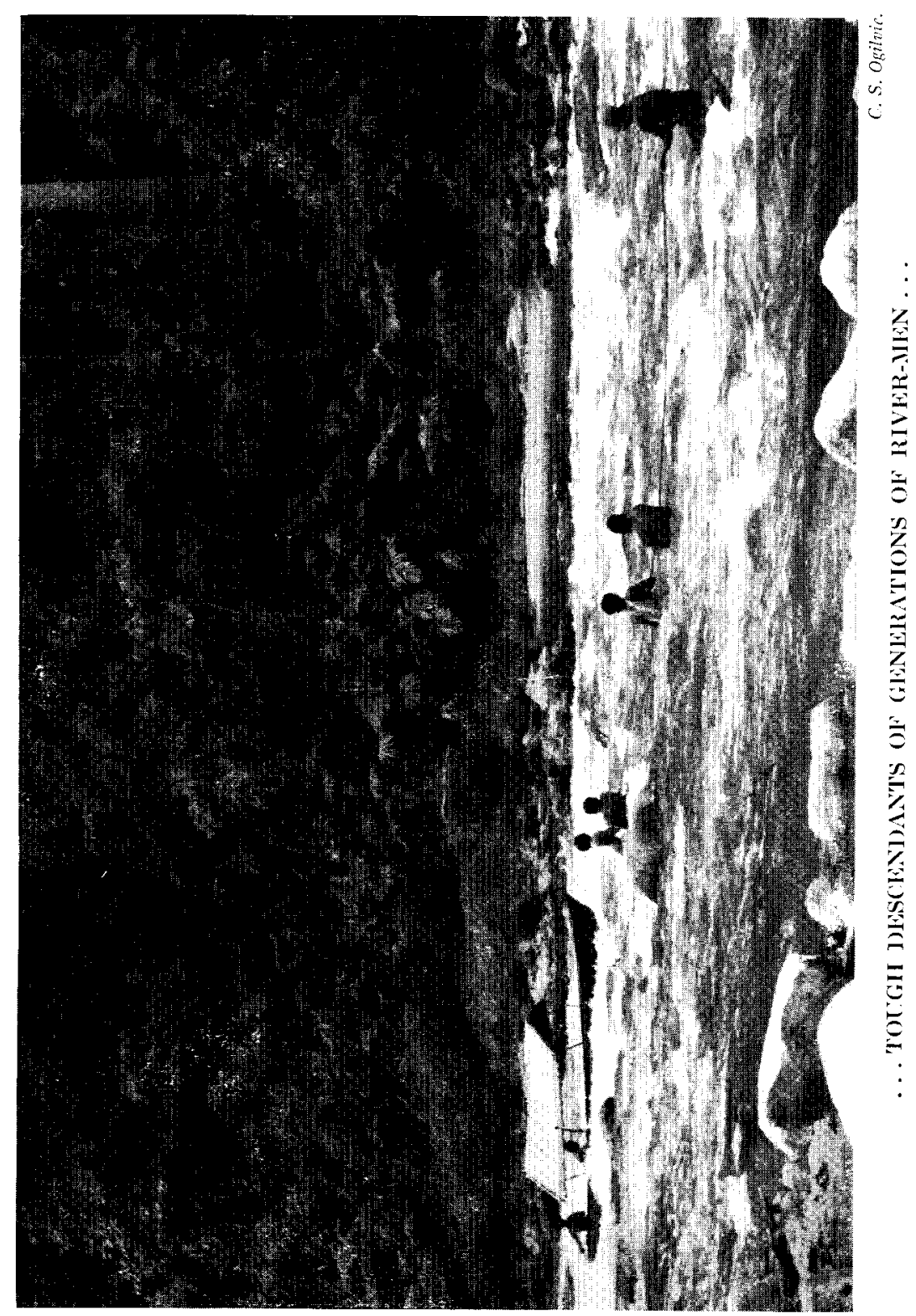




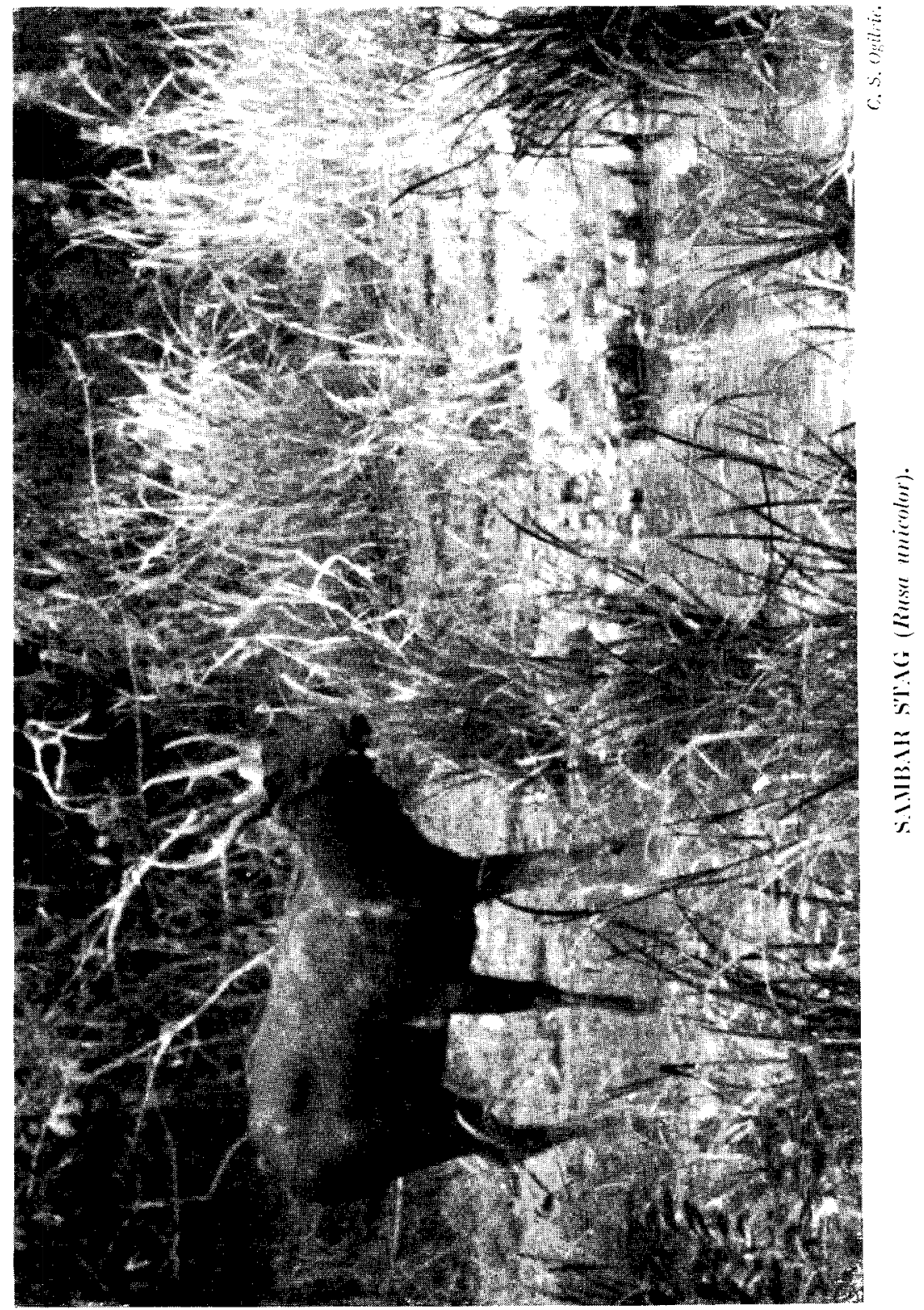


It was remarkable how all hands became jacks of all trades, and some, masters of trades of which they had no previous knowledge. The success of the whole programme is due to Ogilvie's versatility, drive and initiative, but some of his pupils displayed unsuspected aptitudes. Transport of such items as furniture for upwards of seventy miles in outboard motor boats was always one of our major problems and the development of local talent is saving money, giving better results, and, what is still more important, making us independent of contractors, always ready to take advantage of our difficulties and now unwilling to work so far afield.

Almost as soon as serious work commeneed in the Park the bandit situation became grave and a state of emergency was proclaimed. I decided carly that we would have to defer rehabilitation of the Kuala Ngeram and Kuala Toh posts. A reconnaissance trip into this area did not disclose evidence of bandit activity, but it was an old guerilla hideout and too near Gua Musang and Pulai, both places which achieved an unenviable notoriety som after the campaign for suppression of banditry commenced. Batu Lompat on the Kechau was reopened, but although this is near an area known as the haunt of bandits, we took the risk of kceping it up and have had no cause for regrct so far. In the Tembeling Valley rehabilitation had advanced too far to turn back, even if we had wished to do so.

In spite of all setbacks we are going ahead steadily. Erection of permanent buildings at Kuala Tahan will be finished this year, as will the building of permanent ranger's quarters and overnight accommodation for visitors at Kuala Atok. A permanent rest house has been built at Kuala Kenyam, quarters being still in temporary buildings. Temporary halting-bungalows and quarters have been provided at Kuala Trenggan and Kuala Kelapor and we hope to build permanent quarters and a haltingbungalow at Kuala Chamir in 1952. Paths have been reopened and maintained and the salt licks and "padangs" kept up. Hides for photographers are being maintained at suitable places; regular chores include the repair of hides which have proved irresistible to elephants.

Animals in the Tembeling Valley suffered very little during the occupation period. Our opportunities for detailed observation have been limited but a wide variety of animals have been recorded including Elephant, Rhinoceros, Gaur, Sambar, Barking Decr, Tapir, Bear, Tiger, Panther and numerous small mammals. Nearly two hundred varieties of fish have been 
identified and recorded and some interesting observations made of birds and insects.

It is another story on the western side, where a reconnaissance expedition saw very little evidence of the abundant wild life to be found there before the war. Signs of Elephant, Gaur and Rhinoceros were absent from Jenut Recking which was always a well patronized salt lick. One short expedition could not furnish conclusive proof, but we know that the guerillas took toll of the local fauna during the occupation and the area is particularly vulnerable due to its proximity to the railway and the villages of Gua Musang and Merapoh. Once the state of the country will permit of the re-establishment of the posts in this area it is hoped that the situation will improve.

Under existing circumstances " care and maintenance" is the rule. The National Park cannot cater for visitors other than an occasional Government officer travelling on duty or the rare enthusiast who is ready to look after himself. Means and opportunity for research are limited, but steady progress is being made towards a better knowledge of the habits and distribution of the larger mammals. It is hoped that when the country returns to normal an organization will be ready to offer the educational and recreational facilities necessary to ensure public interest and while affording sanctuary, contribute to a better knowledge and understanding of the fauna of this part of the Malay Peninsula.

A list of Senior Staff, reference to publications, and a glossary of Malay words used, will be found in the Appendix.

\section{APPENDIX}

Senion Staft, 1951

Officer-in-Charge.-A. H. Fetherstonhaugh, Chief Game Warden, Federation of Malaya.

Resident Superintendent.-C. S. Ogilvie, Game Warden, Federation of Malaya.

Assistant Superintendent.-Vacant.

Chief Ranger.-Omar bin Bakar, Game Ranger Grade I.

\section{Publications}

1948. Annual Report of The Game Department, Malayan Union for 1947.

1949. Annual Report of The Game Department, Federation of Malaya for 1948. 
1950. Annual Report of The Game Department, Federation of Malaya for 1949.

1951. Nature Notes, King George V National Park, for 1950.

$$
\text { Glossary of Malay Words }
$$

Attap. Thatch (made from the leaves of a ground palm). Gunong. A mountain.

Kampong. A Malay village.

$\boldsymbol{K}$ uala. The confluence of two rivers (always given the name of the lesser stream).

Lunas. 'The kecl of a boat (here applied to the bottom scetion of a native-built river boat hollowed from the trunk of a tree, to which plank sides and a transom for an outboard motor are attached).

Padang. An open space, a plain (here used to denote artificial feeding grounds cleared and maintained to provide grazing for seladang and decr and give opportunities for observing them).

Seladang. The Malayan Gaur (Bibos gaurus hubbacki). 